\title{
SANKSI PIDANA TERHADAP PENIMBUNAN MASKER MEDIS DAN HAND SANITIZER PADA MASA PANDEMI COVID-19
}

\author{
I Gede Aditya Triyana, I Nyoman Gede Sugiartha, Ni Made Sukaryati Karma \\ Fakultas Hukum Universitas Warmadewa, Denpasar-Bali, Indonesia \\ Adityasadega570@gmail.com, nyomansugiarthal4@gmail.com, madesukaryatikarma@gmail.com
}

\begin{abstract}
Abstrak
Terkait proteksi warga dalam pandemi covid-19 yaitu adanya penimbunan masker dan hand sanitizer oleh oknum pelaku bisnis. Saat ini terjadi kelangkaan barang seperti masker dan hand sanitizer. Kejanggalan ini menciptakan kondisi dimana pemerintah dan segenap aparat bersama-sarna memeriksa penyebab terjadinya penimbunan yang mengakibatkan ketersediaan menjadi langka dan harganya melonjak mahal. Penelitian ini menganalisis pengaturan tentang penimbunan barang pada saat terjadi kelangkaan barang menurut UU No.7 tahun 2014 di masa pandemi Covid-19 dan mengkaji sanksi pidana terhadap pelaku penimbunan masker medis dan hand sanitizer dalam UU No. 7 tahun 2014 di masa pandemi Covid-19. Penelitian ini didesain dengan hukum normatif dengan pendekatan Perundang-undangan dan pendekatan konseptual. Adapun data yang digunakan yaitu data primer dan sekunder yang diperoleh dengan cara pencatatan dan wawancara. Hasil penelitian menerangkan bahwa Pengaturan Penimbunan dan pelipatgandaan harga masker dan hand sanitizer dalam hukum pidana Indonesia diatur dalam Pasal 107 Undang-undang Nomor 7 Tahun 2014 tentang Perdagangan, undang-undang tersebut dapat menjadi payung hukum untuk menjerat para pelaku penimbunan dan pelipatgandaan harga masker dan Hand Sanitizer di masa pandemic covid-19. Sanksi pidana tentang tindak pidana penimbunan dan pelipatgandaan harga masker dan hand sanitizer pada masa pandemic covid-19 terdapat pada Pasal 107 Undang-undang nomor 7 Tahun 2014 tentang Perdagangan.
\end{abstract}

Kata Kunci: Masker, Handsanitizer, Pandemi Covid-19, Sanksi Pidana

\begin{abstract}
Regarding the protection of citizens in the COVID-19 pandemic, namely the hoarding of masks and hand sanitizers by business people. There is currently a shortage of items such as masks and hand sanitizers. This discrepancy creates conditions in which the government and all officials jointly examine the causes of hoarding, which results in availability becoming scarce and prices soaring. This study analyzes the regulation of stockpiling goods when there is a shortage of goods according to Law No. 7 of 2014 during the Covid-19 pandemic and examines criminal sanctions against perpetrators of hoarding medical masks and hand sanitizers in Law no. 7 of 2014 during the Covid-19 pandemic. This research is designed with normative law with legislation approach and conceptual approach. The data used are primary and secondary data obtained by recording and interviewing. The results of the study explain that the arrangement for hoarding and doubling the price of masks and hand sanitizers in Indonesian criminal law is regulated in Article 107 of Law Number 7 of 2014 concerning Trade, this law can be a legal umbrella to ensnare the perpetrators of hoarding and doubling the prices of masks and hand sanitizers. Sanitizer during the covid-19 pandemic. Criminal sanctions regarding the crime of hoarding and doubling the price of masks and hand sanitizers during the COVID-19 pandemic are contained in Article 107 of Law Number 7 of 2014 concerning Trade.
\end{abstract}

Keywords: Masks, Handsanitizer, Covid-19 Pandemic, Criminal Sanctions

\section{PENDAHULUAN}

Negara Indonesia merupakan negara hukum. Negara hukum lahir menjadi gagasan atau upaya dan usaha terhadap hak asasi manusia. Negara wajib melindungi dan menghormati Hak Dasar yang bersifat inheren dan kodrati yang dikenal dengan Hak Asasi Manusia (Widodo, 2015). Hak Asasi Manusia merupakan agunan yang harus ditegakkan di Negara Hukum (Arifin \& Lestari, 2019). Sehingga setiap masyarakat memiliki hak yang sama di depan hukum karena terdapat peradilan yang bebas. Setiap individu dapat mengklaim keadilan bagi setiap orang terhadap penyalahgunaan kewenangan dari pihak yang berkuasa. Masyarakat harus patuh terhadap hukum yang terdapat dalam Undang-Undang karena lndonesia adalah negara hukum. Sehingga aturan pidana dapat ditegakkan sebagai upaya penegakkan hukum untuk membangun keamanan dan keadilan di lingkungan rnasyarakat (Sulistyawati, 2018). 
Hukum pidana bagian dari aturan yang berlaku pada tempat tertentu yang rnenjelaskan dasardasar dan mengatur ketentuan mengenai perbuatan yang tak boleh dilakukan, dihentikan yang disertai ancaman pidana bagi barangsiapa yang melakukan. pada hal bagaimana pada yang sudah rnelanggar aturan itu bisa dikenakan sanksi pidana serta cara bagaimana pidana itu bisa terapkan (Hiariej, 2016). Tubuh manusia dapat diserang oleh virus Covid-19 melalui konsumsi kuliner yang berasal menurut satua liar rnisalnya tikus, kelelawar, dan primata. Pada tahun 1960 sampai 2019, ternyata Corona mempunyai poly macam jenisnya, misalnya Alpha Coronavirus, Beta Coronavirus, Gamma Coronavirus, dan Delta Coronavirus. Beberapa menurut genus virus yang hanya bisa menyerang tubuh manusia sampai mengakibatkan meninggal yaitu genus Alpha dan genus Beta.

Tingginya jumlah pasien yang terserang virus covid-19 menciptakan kondisi dimana pemerintah Indonesia menghimbau supaya warga tidak panik dan waspada serta mematuhi kebijakan yang sudah dibentuk misalnya restriksi akses daerah, bekerja di rumah, dan belajardi rumah. Kemenkes RI menciptakan panduan pencegahan dan pengendal ian virus covid-19 dan mempublikasi pada warga 16 Maret 2020 supaya warga bisa mengetahui langkah-langkah pencegahan virus covid19. Berikut beberapa upaya mencegah virus covid-19 yang paling efektif berdasarkan Kemenkes RI antara lai:

1. Melakukan kebersihan tangan memakai Hand Sanitizer apabila tangan tak terlihat kotor atau cuci tangan menggunakan sabun apabila tangan terlihat kotor

2. Menghindari menyentuh hidung, mata, dan ekspresi muka

3. Terapkan etika batuk atau bersin menggunakan menutup hidung dan menggunakan lengan atas atau tisu, kemudian buanglah ke tempat sampah

4. Pakailah masker med is apabila mempunyai tanda-tanda pernapasan dan melakukan kebersihan tangan sesudah membuang masker

5. Menjagajarak (minimal I meter) menurut orang yang mengalami tanda-tanda gangguan pernapasan (Kemenkes, 2020)

Dari beberapa langkah pencegahan virus covid-19 di atas, diketahui fakta bahwa terjadi kelangkaan barang eksklusif misalnya masker dan hand sanitizer, di tengah menyebarnya virus covid-19 di Indonesia. Kejanggalan tentang langkanya barang tadi menciptakan kondisi dimana pemerintah dan segenap aparat negara bersama-sama memeriksa penyebab terjadinya barang yang biasanya gampang didapat sekarang sulit buat ditemukan. Selain masker yang sulit ditemukan, Hand Sanitizer yang mempunyai kiprah yang sangat krusial dalam menjaga tangan supaya permanen steril juga sebagai problem lantaran disamping langka juga masih ada beberapa pelaku bisnis yang sengaja meraup laba melalui pelipatgandaan harga dan penimbunan masker dan hand sanitizer.

Penelitian sebelumnya mengungkapkan penetapan harga, penguasaan pasar, atau pemasaran barang yang mengakibatkan praktik monopoli atau persaingan usaha tidak sehat sansiknya diatur dalam UU Persaingan Usaha (Soleh, 2020). Sekalipun belum ada yang mengatur tentang masker dan hand sanitizizer, namun hakim tetap memeriksa jika kedapatan oknum bisnis yang sengaja melakukan penimbunan barang (Mahendra, 2020); \& (Rahayu, 2020).

Berdasarkan kenyataan lapangan diketahui bahwa Pelaku bisnis yang tidak mengerti bahwa melipat gandakan harga Hand Sanitizer disaat terjadinya kelangkaan barang yang diakibatkan suatu wabah akan terancam hukuman. Seperti pepatah Ubi Societas Ibi lus, yang adalah dimana terdapat warga disitu terdapat aturan. Dengan demikian segala bentuk aktivitas yang merugikan orang lain, merogoh kesempatan ketika terjadi bencana, dan menciptakan kepanikan maka aturan pidana akan berlaku. Maka Penelitian ini menganalisis pengaturan tentang penimbunan barang pada saat terjadi kelangkaan barang menurut UU No.7 tahun 2014 di masa pandemi Covid-19 dan mengkaji sanksi pidana terhadap pelaku penimbunan masker medis dan hand sanitizer dalam UU No. 7 tahun 2014 di masa pandemi Covid-19

\section{METODE PENELITIAN}

Penelitian ini menggunakan penelitian hukum normatif yaitu meletakan aturan menjadi bangunan sistem norma sebagai metode penelitian dalam studi ini mengkaji mengenai asas-asas hukum, doktrin, norrna-norma, kaidah-kaidah terhadap suatu peratuan perundang-undangan. Sumber bahan hukum sekunder dan primer digunakan sebagai sumber bahan hukum dalam studi ini. Data dikumulkan melalui pencatatan dan dokumentasi, Bahan hukum yang telah berhubungan dengan permasalahan 
telah terkumpul selanjutnya dianalisis menggunakan analisa interpretasi hukum agar dapat menjawab permasalahan yang diteliti.

\section{HASIL DAN PEMBAHASAN}

1. Pengaturan Tentang Penimbunan Barang pada Saat Terjadi Kelangkaan Barang Menurut UU No.7 Tahun 2014 pada Masa Pandemi Covid-19

Perdagangan merupakan bagian dari transaksi barang dan jasa di seluruh dunia melalui peralihan hak kepemilikan terhadap suatu barang untuk mendapatkan keuntungan. Transaksi yang berhubungan dengan masker dan hand sanitizer diatur dalam UU tersebut. Tersedianya barang-barang publik dan terhindarnya kegagalan pasar berada dalam pengawasan pemerintah. Sehingga aktivitas perdagangan dan perekonomian diterangkan dalam UU No 7 tahun 2014 tersebut. Lantaran itu, hegemoni pemerintah pada soal ini rnenjadi sangat krusial. hegemoni pemerintah secara pribadi pada penyediaan masker dan hand sanitizer, pengaturan aturan pidana bisa dipakai buat menjerat pihakpihak yang mengakibatkan kelangkaan barang-barang ini. Oleh karenanya, aktivitas-aktivitas yang memang dimaksudkan rnengganggu ketersediaan perdagangan Masker dan hand sanitizer, perlu dipandang lebih pada Undang-Undang Perdagangan. Pasal 107 dalam UU Perdagangan menjelaskan bahwa terdapat peraturan yang mengawasi kegiatan yang dapat menyebabkan kelangkaan barang yang dibutuhkan dalam masa pandemi.

Saat masyarakat mengalami kendala perdagangan yang menyebabkan kenaikan harga dan kelangkaan dalam jumlah dan kurun waktu tertentu, penyimpanan barang utarna yang krusial diarur dalam ketentuan tersebut. Sehingga pelaku bisnis harus mematuhi peraturan yang berlaku. Larangan menimbun barang hams ditegakkan karena merugikan orang banyak. Terdapat perdebatan mengenai hukuman terhadap masyarakat yang rnenimbun Hand Sanitizer dan Masker berdasarkan Pasal 107 UU Perdagangan. Status larangan barang penting atau pokok yang ditimbun atau disimpan tertuang dalam ketenruan tersebut. Perpres No 71 Tahun 2015 mengatur lebih Ianjut mengenai barang penting atau pokok tersebut.

Dalam Perpres ini, barang kebutuhan utama dimaknai menjadi barang yang menyangkut hajat hayati orang menggunakan skala pernenuhan kebutuhan yang tinggi dan sebagai faktor pendukung kesejahteraan warga, sedangkan barang krusial dimaknai menjadi barang strategis yang berperan krusial pada memilih kelancaran pembangunan nasional. Ketentuan barang pokok dijelaskan dalam Perpres tersebut yaitu hasil perikanan dan peternakan, hasil industri, dan hasil pertanian. Sedangkan secara limitatif terdapat contoh barang penting yairu baja ringan, besi baja konstruksi, semen, triplek, gas elpiji 3 kilogram, pupuk, kedelai, jagung, dan benih padi. Berdasarkan contoh barang penting dan barang pokok di atas, tidak ada penyebutan masker dan hand sanitizer dalam kedua batasan limitatif di atas. Meskipun keberadaan kedua jenis barang tersebut sangat penting dan pokok pada masa Pandemi Covid-19. Sehingga tenaga medis dan masyarakat terancam keselamatannya karena kelangkaan yang terjadi. Namun demikian, Perpres No. 71 Tahun 2015 sebenarnya masih memberi peluang bagi perluasan barang pokok dan penting. Sebab, ketentuan Pasal 2 ayat (7) mengatur, Jenis barang kebutuhan pokok dan penting yang telah ditetapkan secara limitatif itu dapat diubah berdasarkan usulan menteri setelah berkoordinasi dengan menteri atau kepala lembaga pemerintah nonkementerian terkait. Sehingga kategori barang penting sangat mungkin dikaitkan pada masker dan hand sanitizer berdasarkan perubahan tersebut. Program pemerintah dapat mendukung pembangunan nasional yang bersifat strategis, sehingga berpeluang untuk menetapkan berbagai jenis barang dalam kategori penting, berdasarkan Perpres di atas. Sudah sepatutnya terdapat perubahan dalam klasifikasi barang penting demi keselamatan tenaga med is dan masyarakat. Untuk menjaga kesehatan dan terhindar dari jeratan Virus Covid-19, keberadaan Hand Sanitizer dan Masker sangat diburuhkan. Dalam menurunkan dan mencegah penyebaran virus yang belum ada obatnya, Pemerintah harus melakukan berbagai cara agar situasi pandemi ini tidak meresahkan masyarakat. Untuk mencapai rujuan tersebut, masyarakat sangat membutuhkan keberadaan Hand Sanitizer dan Masker. Penggunaan kedua barang tersebut sangat dianjurkan oleh pemerintah ketika masyarakat berada dalam ruang publik. Sehingga salah satu jenis barang penting dapat dikaitkan pada Hand Sanitizer dan Masker berdasarkan kondisi di atas.

Aparat penegak hukum dapat menafsirkan penemuan hukum (rechtsvinding) berdasarkan kasus penimbunan Masker dan Hand Sanitizer unruk menindak pelaku. Menurut Purusan Hoge Raad pada 31 Januari 1919, terdapat pemahaman perbuatan melawan hukum sebagaimana dikenal dalam Pasal 
1365 (KUHPerdata) tidak hanya ditafsirkan sebagai perbuatan melawan hukum dalam bentuk yang telah tertulis (written) saja, melainkan juga yang tidak tertulis (unwritten) . Asas legalitas tercanrum pada prinsip hukum pidana dalam purusan kasus tersebut (Haveman, 2002). Terdapat larangan menggunakan analogi sehingga menjadikan asas tersebut dikenal sangat fundamental. Penafsiran yang di luar konteks dari pembuat undang-undang sangat dilarang saat menegakkan hukum pidana bagi penegak hukum. Selain itu, terdapat larangan lain agar tidak menyamakan dengan suatu keadaan yang tidak sama dalam konteks yang ingin dikaji.

Apabila masih terdapat upaya melawan hukum yang berkaitan dengan pelanggaran tersebut, inovasi peraturan secara permanen masih dapat diterapkan. Sifat melawan aturan ini pada suatu tindak pidana diartikan menggunakan merujuk dalam argumentasi bahwa suatu tindakan bisa diklaim tindak pidana apabila sifat tindakan (wesen) tadi (dem Wesen nach) sejalan menggunakan maksud sesuai ketentuan aturan pidana yang dimaksudkan (Utrecht, 1986). Jalan tengah dalam peristiwa ini adalah penggunaan tafsir sistematik sebagai pertimbangan aparat penegak hukum, yaitu sebuah penafsiran yang fokus pada kesamaan peraturan undang-undang lain yang membahas hal yang sama. Landasan ini juga yang sepertinya sebagai dasar terbitnya Peraturan Menteri Perdagangan Nomor 34 Tahun 2020 mengenai Perubahan Kedua Atas Peraturan Menteri Perdagangan Nomor 23 Tahun 2020 mengenai Larangan Sementara Ekspor Antiseptik, Bahan Baku Masker, Alat Pelindung Diri dan Masker, yang telah membahas larangan pengiriman APD ke luar negeri karena kelangkaan barang penting saat pandemi Covid-19. Bukanlah suatu analogi ketika UU Perdagangan dikaitkan dengan Hand Sanitizer dan Masker menjadi barang penting, berdasarkan penafsiran peraturan tersebut. Sehingga peraturan Perundang-undangan yang membahas hal yang sama dapat menggunakan tafsir sistematis. Hal tersebut juga selaras dengan pengakomodasian Peraruran dalam Penetapan Barang Penting pada Perpres No. 71 Tahun 2015, Penetapan barang krusial didasarkan atas sifat barang yang dipercaya strategis pada pembangunan nasional . Persamaan tersebut yang memberi penegasan bahwa Masker dan Hand Sanitizer memang layak dimaknai menjadi satu barang krusial ketika pandemi Covid-19.

Prioritas dalam penetapan hand sanitizer dan masker sebagai barang krusial berkaitan dengan kebijakan dalam ketentuan perundang-undangan. Kebutuhan warga dan kepentingan negara terhadap APD membuat barang ini dilarang untuk dikirim ke luar negeri berdasarkan Peraturan Menteri Perdagangan. Sehingga pelanggaran yang dilakukan oleh pelaku bisnis dalam menimbun Hand Sanitizer dan Masker akan memberikan banyak gejolak dan pertimbangan bagi aparat hukum. Ketua forum pemerintah non-kementerian terkait dan Menteri dapat berkoordinasi untuk melakukan revisi tentang jenis barang utarna dan krusial berdasarkan permasalahan di atas. Pergantian peraturan mengenai jenis barang krusial akan mendorong perubahan status hand sanitizer dan masker oleh Menteri Perdagangan. Sehingga abstrak dalarn penegakan aturan pidana perlindungan konsumen dapat diterapkan melalui klasifikasi hand sanitizer dan masker sebagai barang penting.

\section{Sanksi Pidana Terhadap Pelaku Penimbunan Masker Medis dan Hand Sanitizer dalam Undang-undang no. 7 tahun 2014 pada Pandemi Covid-19}

Politik hukum merupakan legal policy tentang hukum yang akan diberlakukan atau tidak diberlakukan untuk mencapai tujuan negara (Moh, 2011). Untuk mencapai cita-cita bangsa dan tujuan negara, terdapat langkah dan sarana untuk menggunakan hukum sebagai alat (Hartono, 1991). Sedangkan Hukum pidana bukan tujuan pada diri sendiri tetapi ditujukan untuk menegakkan tertib hukum, melindungi masyarakat hukum. Penjagaan tertib sosial untuk sebagian besar sangat tergantung pada paksaan (Remmelink, 2003). Daya paksa memang sangat dibutuhkan buat menertibkan warga lantaran masih banyaknya warga yang tidak menaati aturan. Misalnya kejahatan yang dilakukan para pelaku bisnis ketika wabah virus covid-19 terjadi. Kejahatan penimbunan masker dan hand sanitizer yang dilakukan oleh para pelaku bisnis didasari tidak adanya dasar aturan yang mengatur barang berupa masker dan hand sanitizer serta adanya kesempatan buat mendapatkan laba lebih tinggi. Secara normatif, masker dan hand sanitizer tidak mempunyai dasar aturan, namun hal ini tidak dapat dibiarkan karena aturan diciptakan buat menciptakan ketertiban, kemanfaatan dan keadilan buat warga. Pelaku bisnis yang menimbun barang dan melipatgandakan harga masker dan Hand Sanitizer bisa dikenakan hukuman pidana memakai instrumen aturan yaitu UU No. 7 Tahun 2014 mengenai Perdagangan Undang-undang tadi sangat efektif buat menjerat kejahatan misalnya pelipatgandaan harga masker dan hand sanitizer. Adapun pasal-pasal mengenai kejahatan pelipatgandaan harga hand 
sanitizer yang diatur pada Undang-undang tersebut yakni Pasal 29 ayat (1) Undang-Undang Nomor 7 Tahun 2014 tentang Perdagangan. Mengacu pada pasal ini, pembisnis yang melakukan tindak kejahatan penimbunan dan melipatgandakan harga barang penting dapat dipidana. Terpenuhinya dua unsur yang terdapat dalam pasal tersebut seperti kelangkaan barang dan gejolak harga maka pelaku usaha dapat dipidana. Masker dan Hand Sanitizer pada saat ini menjadi barang penting yang langka akibat peningkatan tingkat ekonomi masyarakat. Sehingga membuat para pelaku usaha mengambil kesempatan untuk meraup keuntungan dengan harga tinggi yang melanggar ketenruan pada pasal tersebut.

Penimbunan dan pelipatgandaan harga masker dan hand sanitizer dapat diberikan hukuman sesuai dengan hukum yang berlaku. Kejanggalan pada saat pihak kepolisian menentukan bahwa pelaku usaha yang menimbun atau melipatgandakan harga masker dan hand sanitizer dapat dipidana. Kejanggalan tersebut terlihat pada klausa barang pokok/barang penting yang ada dalam Pasal 29 ayat (1) U ndang-undang Nomor 7 Tahun 2014 tentang Perdagangan. Mengingat masker dan hand sanitizer bukan tergolong barang penting maka timbul permasalahan hukum yang harus dihadapi oleh penegak hukum. Beberapa barang yang tergolong dalam barang penting berdasarkan Peraruran Presiden Nomor 59 Tahun 2020 tentang Perubahan Atas Peraturan Presiden Nomor 71 Tahun 2015 tentang Penetapan dan Penyimpanan Barang Kebutuhan Pokok dan Barang Penting terdapat dalam Pasal 2 ayat (6) huruf b yaitu benih (benih padi, jagung, dan kedelai), pupuk, gas elpiji 3 (tiga) kilogram, triplek, semen, besi baja konstruksi, dan baja ringan

Jika terdapat tindakan melanggar hukum, penemuan hukum tersebut tetap dapat diterapkan. Sehingga terdapat pendapat suatu tindakan dapat disebut tindak pidana jika sifat tindakan (wesen) tersebut sejalan dengan maksud dari ketentuan hukum pidana yang dimaksudkan . Kepolisian dalam melaksanakan tugasnya pada kasus ini menggunakan tafsiran sistematik, yaitu penafsiran yang fokus pada kesamaan peraturan undang-undang dalam membahas permasalahan yang sama.

Sanksi pidana yang tertera pada Pasal 107 Undang-Undang Nomor 7 Tahun 2014 tentang Perdagangan dalam hal Undang-undang Nomor 7 Tahun 2014 tentang Perdagangan memiliki kendala pada objek yang dituju tidak ada dalam Undang-undang. Semua hakim dianggap mengetahui hukum sehingga pengadilan tidak diijinkan untuk menolak mengadili dan memeriksa suatu kasus meskipun kasus tersebut tidak memiliki dasar hukum. Hal tersebut berdasarkan asas ius curia novit yang menjelaskan bahwa ketertiban dan keamanan masyarakat dapat tercapai melalui penegakan hukum.

Berdasarkan hal itu hakim berwenang untuk menentukan hukum objektif mana yang harus diterapkan baik berasal dari hukum positif atau yurisprudensi atau berdasarkan kebiasaan. Melihat ketenruan tersebut, sudah dapat dipastikan bahwa kejahatan penimbunan dan pelipatgandaan harga masker dan hand sanitizer dapat dikenai sanksi pidana dengan catatan hakim beritikad baik untuk mempertimbangkan bahwa perbuatan tersebut termasuk tindak pidana dengan pertimbangan yurisprudensi dan kebiasaan yang ada di masyarakat. Yurisprudensi merupakan putusan hakim (judge made law) yang diikuti hakim lain dalam perkara serupa (asas similia similibus), kemudian putusan hakim itu menjadi tetap sehingga menjadi sumber hukum. Yurisprudensi dalam prakteknya berfungsi untuk mengubah, mengukuhkan, menciptakan, menghapus, dan memperjelas hukum yang telah hidup dalam masyarakat. Perlunya aturan hukum baru untuk memberikan rasa aman dalam masyarakat serta terwujudnya hukum yang dicita-citakan. Apabila kejahatan penimbunan dan pelipatgandaan harga masker dan Hand Sanitizer tidak dapat dipidana, maka terdapat kesempatan di masa yang akan datang terjadi hal yang sama disaat keadaan tertentu. Terdapat beberapa kasus tindak pidana pelipatgandaan harga hand sanitizer yang terjadi.

\section{SIMPULAN DAN SARAN}

\section{Simpulan}

Dari jasil analisis data, dapat disimpulkan bahwa pengaturan penimbunan dan pelipatgandaan harga masker dan hand sanitizer dalam hukum pidana Indonesia diatur dalam Pasal 107 Undang-undang Nomor 7 Tahun 2014 tentang Perdagangan, undang-undang tersebut dapat menjadi payung hukum untuk menjerat para pelaku penimbunan dan pelipatgandaan harga masker dan Hand Sanitizer di masa pandemic covid-19. Sanksi pidana tentang tindak pidana penimbunan dan pelipatgandaan harga masker dan hand sanitizer pada masa pandemic covid-19 terdapat pada Pasal 107 Undang-undang nomor 7 Tahun 2014 tentang Perdagangan. 


\section{Saran.}

Adapun saran dari peneliti terkait simpulan pada penelitian ini yaitu Kepada pemerintah dan penegak hukum, seharusnya dapat melihat bahwa suatu kejahatan yang nyata walaupun tidak adanya dasar hukum harus tetap ditindak guna menciptakan ketertiban masyarakat. Mengingat bencana covid-19 tidak tahu kapan selesainya. Kepada pelaku alangkah baiknya agar tidak melakukan hal-hal demikian karena meskipun bukan sebagai barang penting atau kebutuhan pokok selama ini namun pada saat bencana covid-19 ini melanda Indonesia maka masker medis dan hand sanitizer berubah menjadi barang penting atau kebutuhan pokok masyarakat di maas panemi ini sebagai perlindung diri.

\section{DAFTAR PUSTAKA}

Arifin, R., \& Lestari, L. E. (2019). Penegakan dan Perlindungan Hak Asasi Manusia di Indonesia dalam Konteks Implementasi Sila Kemanusiaan yang Adil dan Beradab. Jurnal Komunikasi Hukum, 5(2), 12-25.

Hartono, S. (1991). Politik Hukum Menuju Satu Sistem HukumnNasional. Bandung. Alumni.

Haveman, R. H. (2002). The Legality of Adat Criminal Law in Modem Indonesia. Jakarta. Tata Nusa.

Hiariej, E. O. . (2016). Prinsip-prinsip Hukum Pidana. Yogyakarta. Cahaya Atma Pustaka.

Mahendra, F. (2020). Urgensi Penemuan Hukum oleh Hakim Sebagai Upaya Untuk Mewujudkan Keadilan dan Kepastian Hukum dalam Penanganan Kasus Penimbunan Masker dan Hand Sanitizer di Masa Wabah Covid-19. Jurnal Hukum Adigama, 3(2), 1019-1043.

Moh, M. M. (2011). Politik Hukum di Indonesia. Jakarta. Rajawali Pers.

Rahayu, P. (2020). Penerapan Etika Bisnis Islam yang Menimbun Masker saat Ditengah Wabah Covid-19. Journal of Enterprise and Development, 2(2), 57-66.

Remmelink, J. (2003). Hukum Pidana. Jakarta. Grarnedia Pustaka Utama.

Soleh, M. F. (2020). Penimbunan Alat Pelindung Diri pada Masa Pandemi Covid-19: Kajian Hukum Pidana Bidang Perlindungan Konsumen. Undang: Jurnal Hukum, 3(1), 1-31.

Sulistyawati, S. (2018). Penegakkan Hukum Lingkungan Environtment Enforcement) Berbasis Nilainilai Karakter. Jurnal Pengabdian Kepada Masyarakat, 2(1), 122-132.

Widodo, E. T. (2015). Negara Hukum, Konstitusi, dan Demokrasi. University Press. Jember. 